\title{
Transposon Mutagenesis Reveals Differential Pathogenesis of Ralstonia solanacearum on Tomato and Arabidopsis
}

\author{
Yu-Mei Lin, ${ }^{1}$ I-Chun Chou, ${ }_{1}$ Jaw-Fen Wang, ${ }^{2}$ Fang-I Ho, ${ }^{2}$ Yu-Ju Chu, ${ }^{1}$ Pei-Cheng Huang, ${ }^{1}$ Der-Kang Lu, ${ }^{1}$ \\ Hwei-Ling Shen, ${ }^{1}$ Mounira Elbaz, ${ }^{2}$ Shu-Mei Huang, ${ }^{2}$ and Chiu-Ping Cheng ${ }^{1}$ \\ ${ }^{1}$ Graduate Institute of Plant Biology and Department of Life Science, National Taiwan University, Taipei, Taiwan, 106, \\ Republic of China; ${ }^{2}$ AVRDC-The World Vegetable Center, P.O. Box 42, Shanhua, Tainan, Taiwan, 741, Republic of China
}

Submitted 3 April 2008. Accepted 12 May 2008.

\begin{abstract}
Ralstonia solanacearum causes a deadly wilting disease on a wide range of crops. To elucidate pathogenesis of this bacterium in different host plants, we set out to identify $R$. solanacearum genes involved in pathogenesis by screening random transposon insertion mutants of a highly virulent strain, Pss190, on tomato and Arabidopsis thaliana. Mutants exhibiting various decreased virulence levels on these two hosts were identified. Sequence analysis showed that most, but not all, of the identified pathogenesis genes are conserved among distinct $R$. solanacearum strains. A few of the disrupted loci were not reported previously as being involved in $R$. solanacearum pathogenesis. Notably, a group of mutants exhibited differential pathogenesis on tomato and Arabidopsis. These results were confirmed by characterizing allelic mutants in one other $R$. solanacearum strain of the same phylotype. The significantly decreased mutants' colonization in Arabidopsis was found to be correlated with differential pathogenesis on these two plants. Differential requirement of virulence genes suggests adaptation of this bacterium in different host environments. Together, this study reveals commonalities and differences of $R$. solanacearum pathogenesis on single solanaceous and nonsolanaceous hosts, and provides important new insights into interactions between $R$. solanacearum and different host plants.
\end{abstract}

Additional keywords: murI, nlpD, pal, tolA, tolQ.

Ralstonia solanacearum is a gram-negative, aerobic rod bacterium belonging to $\beta$-proteobacteria. This bacterium is a soilborne pathogen and can cause lethal wilt diseases on a wide range of plant species, including monocots and dicots (Hayward 1991). Based on biochemical, molecular, and metabolic characteristics, $R$. solanacearum can be classified into four phylotypes, five biovars, five races, and many strains (Denny 2006). The $R$. solanacearum genome is composed of two circular replicons consisting of a chromosome and a megaplasmid. The complete genome of $R$. solanacearum strain GMI1000 (phylotype I, biovar 3, race 1) (Salanoubat et al. 2002) and genome drafts of three other strains of different

Corresponding author: C.-P. Cheng; Telephone: +886-2-3366-3793; Fax +886-2-2391-8940; E-mail: chiupingcheng@ ntu.edu.tw

Y.-M. Lin and I-C. Chou contributed equally to this work.

* The $\boldsymbol{e}$-Xtra logo stands for "electronic extra" and indicates that a supplemental figure is published online. origins have become available (Gabriel et al. 2006) (C. A. Boucher, unpublished data).

To successfully establish a pathogenic interaction with its hosts, $R$. solanacearum has to win many "battles" throughout its journey from the soil up into host stem. A large battery of specialized gene products is required to accomplish tasks at different steps of the infection process, including root attachment and colonization, nutrient acquisition, multiplication, migration through the intercellular spaces, penetration and colonization of xylem, and avoidance or suppression of host defenses. Information accumulated to date has provided an overall picture of the mechanism of $R$. solanacearum pathogenesis and genes involved, with the Phc system as the core of the complex regulatory network governing this character (Genin and Boucher 2004; Mole et al. 2007; Schell 2000). However, our knowledge of pathogenesis of this very "environmentally conscious" bacterium is still incomplete. With the availability of $R$. solanacearum genome sequences, new virulence determinants putatively involved in various aspects of bacterial pathogenesis have been identified by bioinformatics approaches (Gabriel et al. 2006; Salanoubat et al. 2002) (C. A. Boucher, unpublished data). However, the actual functions and roles of these genes in $R$. solanacearum pathogenesis often remain to be determined.

Despite the bacterium's wide host range, studies regarding systematic identification and functional study of $R$. solanacearum genes involved in pathogenesis were carried out mainly on solanaceous species, mostly on tomato and tobacco plants. The molecular mechanism of $R$. solanacearum pathogenesis on nonsolanaceous species remains to be elucidated. Studies have shown that strains isolated from perilla, anthurium, and loofah are pathogenic on other common solanaceous hosts but most strains from solanaceous hosts are not pathogenic on these hosts (Hsu et al. 1993; Pan et al. 1996; Su and Leu 1995). A systematic comparison of the molecular pathogenesis mechanism between solanaceous and nonsolanaceous plants could lead to a better understanding of host specificity of $R$. solanacearum. Arabidopsis has been recognized as a useful model plant system for the study of plant-pathogen interactions, and has been used as a nonsolanaceous species to study $R$. solanacearum-host interactions (Deslandes et al. 2003; Godiard et al. 2003; Hirsch et al. 2002).

Although bioinformatic tools are useful for genome-wide identification of candidate pathogenesis-related genes, certain genes involved in multiple facets of pathogenesis may not necessarily be identifiable in silico. This is particularly true in the case of genes that encode hypothetical proteins, whose functions remain to be established. Consequently, 
large-scale bioassay-based screening for pathogenesis-related genes remains essential for the identification of new pathogenicity genes. For example, in vivo expression technology (IVET) has been used to screen for $R$. solanacearum genes expressed during bacterial growth on tomato plants (Brown and Allen 2004). Specific secretome analysis system was also employed to identify $R$. solanacearum virulence factors (González et al. 2007). Additionally, a transposoninsertion mutagenesis approach was used to search for $R$. solanacearum GMI1000 genes required for triggering the hypersensitive response on tobacco plants (Boucher et al. 1985). To date, these studies remain the only systematic screening for pathogenicity genes that have been carried out on this organism.

The objective of this study was to explore the molecular mechanisms governing susceptible interactions between $R$. solanacearum and two different plant hosts. We set out to screen transposon insertion bacterial mutants for reduced virulence on tomato and Arabidopsis. An improved Tn5 approach, which allowed efficient generation of large quantities of mutants as well as rapid determination of the flanking sequences, was employed. Strain Pss 190 (phylotype I, biovar 4, race 1), isolated from tomato in Taiwan, was selected to generate populations of transposon-inserted mutants. This strain exhibits unusually high virulence level on tomato (Jaunet and Wang 1999). The resistance in tomato cv. Hawaii 7996, known to be the most stable resistance source (Wang et al. 1998), can be totally broken down by Pss190. Our mutant screenings led to identification of a set of mutants encompassing both previously known as well as a new locus involved in $R$. solanacearum pathogenicity, and in adaptation in different host environments. The results reported here provide new insights relative to $R$. solanacearum pathogenesis on solanaceous and nonsolanaceous host species.

\section{RESULTS}

Screening for $\boldsymbol{R}$. solanacearum mutants

with altered pathogenicity.

Under the experimental conditions used to screen mutants, the wild-type strain Pss 190 caused complete wilting on tomato cv. L390 within 4 days postinoculation (DPI) by stem puncturing, and was able to kill $100 \%$ of Arabidopsis seedlings within 14 DPI. Mutants exhibiting various decreased virulence levels on tomato plant $21 \mathrm{DPI}$ and causing a survival rate of Arabidopsis seedlings higher than 80\% 14 DPI were selected. After confirmation by performing three additional assays, 13 mutants and 21 mutants reproducibly displaying various degrees of virulence reduction on tomato and Arabidopsis plants were identified out of 3,056 and 2,889 mutants tested, respectively (Table 1). Southern hybridization revealed a single transposon insertion in each of these mutants (data not shown).

\section{Identification of the disrupted loci in $R$. solanacearum mutants.}

The genomic regions flanking the transposon insertion sites were determined by direct sequencing and the genes and loci were designated based on GMI1000 genome (Table 1). The 13 mutants identified on tomato all possessed a transposon inserted in a putative open-reading frame (ORF) and resulted in disruption of 12 loci (Table 1). Among these loci, a few wellknown pathogenicity genes were identified, including $p h c B$, phcA, hrpG, and pilD. In addition, RSp1007 and RSp1010 are located in the 18-kb eps gene cluster required for exopolysaccharide (EPS) biosynthesis and export (Denny and Baek 1991; Huang and Schell 1995). Furthermore, the identified loci included gene-encoding proteins involved in general secretory pathway ( $g s p L, g s p D$, and $g s p E)$ and carbohydrate metabolism (pgk and hpaIl).

Table 1. Pathogenesis-defective Ralstonia solanacearum mutants identified in this study and the tagged loci

\begin{tabular}{|c|c|c|}
\hline $\begin{array}{l}\text { Transposon } \\
\text { insertion site }^{\mathrm{a}}\end{array}$ & $\begin{array}{c}\text { No. of } \\
\text { mutants }\end{array}$ & Description \\
\hline \multicolumn{3}{|l|}{ Tomato } \\
\hline $\operatorname{RSc} 2735(p h c B)$ & 2 & Regulatory protein \\
\hline $\mathrm{RSc} 2748(p h c A)$ & 1 & A LysR family transcriptional regulator, virulence genes transcriptional regulator \\
\hline $\mathrm{RSp} 0852(h r p G)$ & 1 & Transcription regulator protein \\
\hline RSc2827 (pilD) & 1 & Probable type 4 prepilin peptidase; bifunctional: leader peptidase and $\mathrm{N}$-methyltransferase transmembrane protein \\
\hline RSc3111 (gspL) & 1 & Probable general secretory pathway $L$ transmembrane protein \\
\hline $\mathrm{RSc} 3114(g s p D)$ & 1 & Probable general secretory pathway D transmembrane protein \\
\hline RSp1007 & 1 & Putative acetyl transferase protein \\
\hline RSc0571 (pgk) & 1 & Probable phosphoglycerate kinase protein \\
\hline RSc1591 (hpaI1) & 1 & Putative 2,4-dihydroxyhept-2-ene-1,7-dioic acid aldolase oxidoreductase protein \\
\hline RSp1010 & 1 & hypothetical protein \\
\hline $\mathrm{RSc} 3115(g s p E)$ & 1 & Probable general secretion pathway protein $\mathrm{E}$ \\
\hline \multicolumn{3}{|l|}{ Arabidopsis } \\
\hline $\mathrm{RSc} 0903(\mathrm{serC})$ & 3 & Probable phosphoserine aminotransferase (PSAT) protein \\
\hline RSc1981 (trpA) & 1 & Probable tryptophane synthase alpha chain protein \\
\hline $\mathrm{RSc} 0454$ & 1 & Putative Fe-S oxidoreductase; FAD/FMN-containing dehydrogenase oxidoreductase protein \\
\hline $\mathrm{RSc} 0411$ & 1 & Probable transmembrane protein \\
\hline $\mathrm{RSc} 0353(\mathrm{gpmA})$ & 1 & Probable 2,3-bisphosphoglycerate-dependent phosphoglycerate mutase \\
\hline RSc1956 (murI) & 1 & Probable glutamate racemase protein \\
\hline $\mathrm{RSc} 0565(r f a F)$ & 1 & Probable ADP-heptose--lipopolysaccharide heptosyltransferase II protein \\
\hline $\mathrm{RSc} 1326$ & 3 & Probable aspartate aminotransferase protein \\
\hline $\mathrm{RSc} 2464(\operatorname{clp} A)$ & 2 & Probable ATP-dependent protease (ATP-binding specificity subunit) protein \\
\hline $\mathrm{RSc} 0734$ (tolA) & 1 & Probable TolA-related transport transmembrance protein \\
\hline $\mathrm{RSc0736}(\mathrm{pal})$ & 2 & Probable peptidoglycan-associated lipoprotein precursor \\
\hline $\mathrm{RSc0732(tolQ)}$ & 1 & Probable TolQ-related transport transmembrane protein \\
\hline $\mathrm{RSc} 2684$ (proC) & 1 & Probable oxidoreductase pyrroline-5-carboxylate reductase signal peptide protein \\
\hline $\mathrm{RSc} 1206$ & 1 & Probable lipoprotein NlpD \\
\hline $\mathrm{RSc} 0500(\operatorname{ruvB})$ & 1 & Probable holiday junction DNA helicase RuvB protein \\
\hline
\end{tabular}

\footnotetext{
${ }^{a}$ Mutants identified on tomato and Arabidopsis. Gene and locus designations are based on GMI1000 genome.

${ }^{b}$ Number of identified independent mutants with a transposon insertion at different positions of the gene. Except for the case of RSc1591 (hpaI1), the orientation of the nptII promoter in the transposon was the same as that of the inserted genes.
} 
Sequence analysis revealed that, in the 21 mutants identified on Arabidopsis, the transposon had inserted in a putative ORF; multiple independent insertions for several genes were isolated, resulting in disruption of 15 loci. Four loci ( $\operatorname{ser} C$, $\operatorname{trp} A$, $\mathrm{RSc} 1326$, and proC) are homologous to genes encoding amino acid biosynthetic enzymes. RSc0454 and RSc0411 are predicted to encode a putative $\mathrm{Fe}-\mathrm{S}$ oxidoreductase and a probable transmembrane protein of unknown function, respectively. $\mathrm{RSc0353}(\mathrm{gpmA})$ is a homologue of genes encoding phosphoglycerate mutases involving in the Embden-Meyerhoff pathway. Loci homologous to genes functioning in biosynthesis of cell envelope ( $m u r I)$, lipopolysaccharides $(r f a F)$, transporter proteins (tolA and tolQ), or lipoproteins (pal and RSc1206) were also identified. RSc2464 and RSc0500 are homologous to genes encoding protease ClpA and DNA repair protein RuvB, respectively. Moreover, a GMI1000-based genome map predicted that tolQ, tolA, and pal are organized in a cluster.

\section{Pathogenesis of $\boldsymbol{R}$. solanacearum mutants selected from tomato screenings.}

The pathogenesis of the identified mutants was further evaluated on 3-week-old tomato and 4-week-old Arabidopsis plants in a comparative and quantitative manner (Table 2). The results showed that all mutants identified on tomato consistently exhibited decreased virulence on tomato plants when inoculated by root drench. Most of the mutants were defective in their colonization of collars as well as their upward movement inside plants. Interestingly, when the mutants were introduced into plants by stem puncture, the mutant disrupted in hpaIl behaved as fully virulent whereas the others remained defective in pathogenesis. Furthermore, all of these mutants consistently displayed decreased virulence on Arabidopsis plants as well (Table 2).

\section{Pathogenesis of $\boldsymbol{R}$. solanacearum mutants selected from Arabidopsis screenings.}

All mutants identified on Arabidopsis seedlings exhibited various decreased virulence levels on 4-week-old Arabidopsis plants (Table 3 ). When analyzing colonization at the collar region, these mutants behaved similarly to the wild-type parental strain. This difference could be due to the direct introduction of the bacterium by root cutting and the short distance from the cut point to the collar region. However, most mutants were significantly defective on upward movement in Arabidopsis plants, except for the mutants disrupted in proC, RSc1206, or $\operatorname{ruvB}$, which were less defective.

When these mutants were introduced into tomato plants by stem puncture, mutants disrupted in $\operatorname{ser} C, \operatorname{trp} A, \mathrm{RSc} 0454$, and RSc0411 failed to cause symptoms; mutants disrupted in gpmA and $r f a F$ exhibited only moderate virulence; and the other mutants displayed full pathogenesis compared with the wild-type parental strain. When introduced into tomato plants by root drench, the mutants consistently displayed a decreased virulence level similar to that brought about by stem puncture, except for the mutant disrupted in murI or RSc1326, which caused no or only mild wilting. Among the eight mutants showing no or very low virulence on tomato plants (disease score lower than 1.0) when inoculated by root drench, two were not impaired in collar colonization, whereas all were impaired in upward movement.

Notably, comparative pathogenesis studies of the mutants on tomato and Arabidopsis plants revealed that some aspects of $R$. solanacearum pathogenesis on these plants are different (Table 3). For example, 7 of the 15 mutants identified on Arabidopsis displayed virulence reduction on Arabidopsis plants but exhibited high virulence on tomato with a disease index equal to or higher than 3.4. To assess whether differential pathogenesis of these mutants on the two plant species is due to the differences of the two experimental conditions, selected mutants were subjected to further pathogenesis assays on tomato plants under conditions used for Arabidopsis assays. The results showed that the mutants consistently remained virulent on tomato under these experimental conditions (data not shown).

\section{Growth of $R$. solanacearum mutants on media.}

To determine whether the reduced virulence of the mutants was due to growth defects, several media were used to evaluate their growth and EPS production potential (Table 4). The media used included rich 2,3,5-triphenyl tetrazolium chloride (TTC) medium, minimal medium (M9), and Murashige and Skoog (MS) agar medium, which was used in the original screening on Arabidopsis seedlings. Moreover, their growth on

Table 2. Reactions of 3-week-old tomato and 4-week-old Arabidopsis when inoculated with Ralstonia solanacearum mutants identified from tomato screenings

\begin{tabular}{|c|c|c|c|c|c|c|c|c|c|}
\hline \multirow[b]{3}{*}{ Transposon insertion ${ }^{a}$} & \multirow[b]{3}{*}{ Puncture $(\%)^{\mathrm{b}}$} & \multicolumn{8}{|c|}{ Drench } \\
\hline & & \multicolumn{4}{|c|}{ Tomato } & \multicolumn{4}{|c|}{ Arabidopsis } \\
\hline & & Score $^{c}$ & $\mathbf{B}(+/ \mathbf{T})^{\mathbf{d}}$ & $\mathbf{M}(+/ \mathbf{T})^{\mathbf{d}}$ & Reaction $^{\mathrm{e}}$ & Score $^{c}$ & $C(+/ T)^{d}$ & $\operatorname{Mf}(+/ T)^{d}$ & Reaction $^{\mathrm{e}}$ \\
\hline Wild type (nil) & 100 & 5.0 & - & - & $\mathrm{S}$ & 3.6 & - & - & $\mathrm{S}$ \\
\hline $\mathrm{RSc} 2735(p h c B)$ & 0 & 0.0 & $2 / 12$ & $0 / 12$ & $\mathrm{R} / \mathrm{B}^{-} \mathrm{M}^{-}$ & 0.2 & $10 / 10$ & $13 / 30$ & $\mathrm{R} / \mathrm{M}^{-}$ \\
\hline RSc2748 (phcA) & 0 & 0.0 & $1 / 12$ & $0 / 12$ & $\mathrm{R} / \mathrm{B}^{-} \mathrm{M}^{-}$ & 0.6 & $6 / 6$ & $5 / 18$ & $\mathrm{R} / \mathrm{M}^{-}$ \\
\hline RSp0852 (hrpG) & 0 & 0.0 & $1 / 12$ & $0 / 12$ & $\mathrm{R} / \mathrm{B}^{-} \mathrm{M}^{-}$ & 0.3 & $8 / 9$ & $7 / 27$ & $\mathrm{R} / \mathrm{M}^{-}$ \\
\hline RSc2827 (pilD) & 11 & 0.3 & $3 / 11$ & $1 / 11$ & $\mathrm{R} / \mathrm{B}^{-} \mathrm{M}^{-}$ & 0.4 & $8 / 10$ & $4 / 30$ & $\mathrm{R} / \mathrm{M}^{-}$ \\
\hline RSc3111 ( $g s p L)$ & 0 & 0.4 & 9/9 & $7 / 9$ & $\mathrm{R}$ & 0.3 & $7 / 10$ & $1 / 30$ & $\mathrm{R} / \mathrm{M}^{-}$ \\
\hline $\mathrm{RSc} 3114(g s p D)$ & 0 & 0.8 & $3 / 10$ & $1 / 10$ & $\mathrm{R} / \mathrm{B}^{-} \mathrm{M}^{-}$ & 0.4 & $8 / 10$ & $8 / 30$ & $\mathrm{R} / \mathrm{M}^{-}$ \\
\hline RSp1007 & 11 & 0.8 & $3 / 9$ & $1 / 9$ & $\mathrm{R} / \mathrm{B}^{-} \mathrm{M}^{-}$ & 0.1 & $8 / 11$ & $6 / 33$ & $\mathrm{R} / \mathrm{M}^{-}$ \\
\hline RSc0571 (pgk) & 67 & 1.0 & $4 / 9$ & $1 / 9$ & $\mathrm{R} / \mathrm{B}^{-} \mathrm{M}^{-}$ & 0.5 & $6 / 7$ & $5 / 21$ & $\mathrm{R} / \mathrm{M}^{-}$ \\
\hline RSc1591 (hpaII) & 100 & 1.1 & $5 / 5$ & $2 / 5$ & $\mathrm{R} / \mathrm{M}^{-}$ & 0.8 & $4 / 4$ & $4 / 12$ & $\mathrm{R} / \mathrm{M}^{-}$ \\
\hline RSp1010 & 56 & 1.7 & $5 / 6$ & $0 / 6$ & $\mathrm{R} / \mathrm{M}^{-}$ & 0.5 & $6 / 7$ & $7 / 21$ & $\mathrm{R} / \mathrm{M}^{-}$ \\
\hline RSc3115 ( $g s p E)$ & 0 & 1.8 & $7 / 7$ & $2 / 7$ & $\mathrm{R} / \mathrm{M}^{-}$ & 0.6 & $6 / 7$ & $0 / 21$ & $\mathrm{R} / \mathrm{M}^{-}$ \\
\hline
\end{tabular}

a Mutants with transposon insertion in the same locus exhibited consistent pathogenesis. Only the pathogenesis data of a representative mutant strain is shown here.

${ }^{\mathrm{b}}$ Percentage of wilted plants recorded 21 days postinoculation (DPI) when the mutants were inoculated by puncturing into leaf axis.

${ }^{\mathrm{c}}$ Mean severity score based on symptoms observed 21 DPI as described in Materials and Methods.

${ }^{\mathrm{d}}$ Presence of $R$. solanacearum on stem base (B) or midstem (M) of tomato, or collar (C) or midpoint (5 cm above stem) of flower stalk (Mf) of Arabidopsis presented as number of positive isolation (+) versus number of total samples $(\mathrm{T}) ;-$ indicates that plants of the resistant reaction were not assayed.

e Interaction summary present as susceptible reaction (S) where severity score $\geq 2.4$ (in Arabidopsis) or $\geq 3.0$ (in tomato) or resistant reaction (R) where severity score $<2.4$ or 3 in Arabidopsis or tomato, respectively. Deficiency in colonization capacity in R reaction $(-)$ when percentage of colonization $\leq 50 \%$ at stem base (B), collar (C), or midpoint (M) samples. 
TTC agar medium containing sodium dodecyl sulfate (TTCSDS) was also assessed to determine whether these mutants could be defective in envelope integrity, which is a trait related to virulence (Titarenko et al. 1997). The results showed that most of the mutants identified on tomato multiplied normally on all test media, except for the mutants disrupted in pilD, pgk, or hpaIl. In addition, colonies of most mutants were fluidal, while four of the mutants were dry and apparently impaired on EPS production as judged from colony fluidity. On the other hand, the overall growth of most mutants identified by Arabidopsis-based screening was comparable with that of the wildtype strain on TTC plates but not on other media. Colony fluidness of all of the mutants identified on Arabidopsis was similar to that of the wild-type strain. The overall growth of selected mutants exhibiting defective pathogenesis (murl) or differential pathogenesis (tolA, tolQ, pal, and RSc1206) in liquid minimal medium over time was further assessed. These mutants displayed slightly delayed or lower growth as compared to that of the wild-type strain (Supplementary Fig. S1).

\section{Confirmation of candidate pathogenesis-related loci.}

From our screenings, multiple independent insertions for clpA and pal were isolated (Table 1), and these allelic mutants possessed consistent in vitro phenotypes and pathogenesis on tomato and Arabidopsis (data not shown), supporting the idea that the transposon insertions in these loci were the cause of the altered characteristics of the mutants. To provide further evidence that the transposon insertions were responsible for the altered phenotypes of the mutants, allelic mutants carrying the transposon insertions were generated in the genetic background of Pss4, another strain of phylotype I. This was because strain Pss190 was incompetent for genomic DNA homologous recombination via natural transformation. All of the Pss4 allelic mutants behaved similarly with their corresponding Pss190 mutants on TTC, TTC+SDS, and M9 agar media (data not shown). Results of pathogenesis assays carried out on selected Pss4 allelic mutants of our interest (murI, tolA, tolQ, pal, and RSc1206) showed that the test mutants exhibited pathogenesis on tomato and Arabidopsis similar to their Pss 190 counterparts (Table 5), further linking the virulence reduction with the transposon insertions.

\section{Differential pathogenesis is correlated with colonization capability of mutants in hosts.}

To further elucidate the nature of differential pathogenesis of mutants on tomato and Arabidopsis, the in planta colonization level of selected mutants species was assessed (Table 6). Internal bacterial population in tomato and Arabidopsis plants was determined 7 and 21 PDI, respectively, when the wildtype strain Pss190 began to cause complete wilting on these plants. SM1 medium (TTC medium supplemented with $0.01 \%$ polymyxin B sulfate, $0.002 \%$ tyrothricin, $0.005 \%$ chloramphenicol, $0.005 \%$ cycloheximide, and $0.005 \%$ crystal violet)was used in these assays to evaluate multiplication of the wild-type strain, whereas TTC agar medium containing kanamycin was used for the mutants. This is because some of mutants displayed reduced growth on SM1 medium (data not shown). The proportions of positively colonized tomato plants caused by each test mutant 7 PDI was similar to that caused by the wild type, except the mutant disrupted in tolA. This suggests that the mutants could infect tomato as efficiently as the wild type. The tolA mutant caused slower early symptom development but could reach maximum severity 21 DPI similarly to the wild type in other experiments (data not shown). The in planta population of the test mutants in the stem base and midstem of tomato plants effectively infected by the bacteria was similar to that of the wild-type strain. However, except for the mutant disrupted in RSc1206, colonization of mutants in the Arabidopsis collar was not as effective as that of the wild-type strain, and defects in colonization of the mutants were even more remarkable in Arabidopsis flower stalks. These results suggested that the reduced capability of these mutants to colonize inside Arabidopsis is correlated to the differential pathogenesis observed on tomato and Arabidopsis.

Table 3. Reactions of 3-week-old tomato and 4-week-old Arabidopsis when inoculated with Ralstonia solanacearum mutants identified from Arabidopsis screenings

\begin{tabular}{|c|c|c|c|c|c|c|c|c|c|}
\hline \multirow[b]{3}{*}{ Transposon insertion ${ }^{\mathrm{a}}$} & \multirow[b]{3}{*}{ Puncture $(\%)^{\mathbf{b}}$} & \multicolumn{8}{|c|}{ Drench } \\
\hline & & \multicolumn{4}{|c|}{ Tomato } & \multicolumn{4}{|c|}{ Arabidopsis } \\
\hline & & Score $^{c}$ & $B(+/ T)^{d}$ & $\mathbf{M}(+/ \mathbf{T})^{\mathbf{d}}$ & Reaction $^{\mathrm{e}}$ & Score $^{c}$ & $C(+/ T)^{d}$ & $\operatorname{Mf}(+/ T)^{d}$ & Reaction $^{\mathrm{e}}$ \\
\hline Wild-type (nil) & 100 & 5.0 & - & - & $\mathrm{S}$ & 3.6 & - & - & $\mathrm{S}$ \\
\hline $\mathrm{RSc} 0903(\operatorname{serC})$ & 0 & 0.3 & $0 / 11$ & $0 / 11$ & $\mathrm{R} / \mathrm{B}^{-} \mathrm{M}^{-}$ & 0.0 & $12 / 12$ & $7 / 36$ & $\mathrm{R} / \mathrm{M}^{-}$ \\
\hline RSc1981 (trpA) & 0 & 0.0 & $1 / 12$ & $0 / 12$ & $\mathrm{R} / \mathrm{B}^{-} \mathrm{M}^{-}$ & 0.2 & $9 / 10$ & $14 / 30$ & $\mathrm{R} / \mathrm{M}^{-}$ \\
\hline $\mathrm{RSc} 0454$ & 0 & 0.0 & $3 / 12$ & $0 / 12$ & $\mathrm{R} / \mathrm{B}^{-} \mathrm{M}^{-}$ & 0.3 & $8 / 10$ & $2 / 30$ & $\mathrm{R} / \mathrm{M}^{-}$ \\
\hline RSc0411 & 0 & 0.0 & $1 / 12$ & $0 / 12$ & $\mathrm{R} / \mathrm{B}^{-} \mathrm{M}^{-}$ & 0.0 & $9 / 12$ & $10 / 35$ & $\mathrm{R} / \mathrm{M}^{-}$ \\
\hline $\mathrm{RSc} 0353(\mathrm{gpmA})$ & 33 & 0.0 & $5 / 12$ & $1 / 12$ & $\mathrm{R} / \mathrm{B}^{-} \mathrm{M}^{-}$ & 0.4 & $7 / 9$ & $5 / 26$ & $\mathrm{R} / \mathrm{M}^{-}$ \\
\hline RSc1956 (murI) & 89 & 0.0 & $12 / 12$ & $4 / 12$ & $\mathrm{R} / \mathrm{M}^{-}$ & 0.1 & $9 / 11$ & $1 / 33$ & $\mathrm{R} / \mathrm{M}^{-}$ \\
\hline $\mathrm{RSc} 0565(r f a F)$ & 56 & 1.2 & $0 / 10$ & $0 / 10$ & $\mathrm{R} / \mathrm{B}^{-} \mathrm{M}^{-}$ & 0.3 & $7 / 9$ & $1 / 24$ & $\mathrm{R} / \mathrm{M}^{-}$ \\
\hline RSc1326 & 89 & 1.2 & $7 / 7$ & $3 / 7$ & $\mathrm{R} / \mathrm{M}^{-}$ & 1.2 & $6 / 7$ & $2 / 21$ & $\mathrm{R} / \mathrm{M}^{-}$ \\
\hline RSc2464 (clpA) & 100 & 3.4 & - & - & $\mathrm{S}$ & 0.3 & 9/9 & $13 / 27$ & $\mathrm{R} / \mathrm{M}^{-}$ \\
\hline RSc0734 (tolA) & 100 & 3.9 & - & - & $\mathrm{S}$ & 0.2 & $9 / 10$ & $5 / 30$ & $\mathrm{R} / \mathrm{M}^{-}$ \\
\hline $\mathrm{RSc} 0736(\mathrm{pal})$ & 100 & 3.9 & - & - & $\mathrm{S}$ & 0.6 & $6 / 6$ & $6 / 18$ & $\mathrm{R} / \mathrm{M}^{-}$ \\
\hline $\mathrm{RSc0732(tolQ)}$ & 100 & 4.3 & - & - & $\mathrm{S}$ & 0.5 & $7 / 8$ & $7 / 24$ & $\mathrm{R} / \mathrm{M}^{-}$ \\
\hline $\mathrm{RSc} 2684$ (proC) & 100 & 4.5 & - & - & $\mathrm{S}$ & 1.1 & $6 / 6$ & $10 / 18$ & $\mathrm{R}$ \\
\hline RSc1206 & 100 & 4.6 & - & - & $\mathrm{S}$ & 1.1 & $6 / 6$ & $12 / 18$ & $\mathrm{R}$ \\
\hline $\mathrm{RSc} 0500(r u v B)$ & 100 & 4.7 & - & - & $S$ & 1.6 & $3 / 3$ & $5 / 9$ & $\mathrm{R}$ \\
\hline
\end{tabular}

${ }^{a}$ Mutants with transposon insertion in the same locus exhibited consistent pathogenesis. Only the pathogenesis data of a representative mutant strain is shown here.

${ }^{\mathrm{b}}$ Percentage of wilted plants recorded 21 days postinoculation (DPI) when the mutants were inoculated by puncturing into leaf axis.

${ }^{\mathrm{c}}$ Mean severity score based on symptoms observed and the presence of $R$. solanacearum analyzed in different plant tissues 21 DPI.

${ }^{\mathrm{d}}$ Presence of $R$. solanacearum on stem base (B) or midstem (M) of tomato, or collar (C) or midpoint (5 cm above stem) of flower stalk (Mf) of Arabidopsis presented as number of positive isolation (+) versus number of total samples $(\mathrm{T}) ;-$ indicates that plants of the resistant reaction were not assayed.

e Interaction summary present as susceptible reaction (S) where severity score $\geq 2.4$ (in Arabidopsis) or $\geq 3.0$ (in tomato) or resistant reaction (R) where severity score $<2.4$ or 3 in Arabidopsis or tomato, respectively. Deficiency in colonization capacity in $\mathrm{R}$ reaction $(-)$ when percentage of colonization $\leq 50 \%$ at stem base (B), collar (C), or midpoint (M) samples. 


\section{DISCUSSION}

Identification of $R$. solanacearum murI as a new pathogenesis-related gene.

The mutant disrupted in RSc1956 exhibited normal characteristics in various media and colonized collars normally; however, its upward movement in stems was impaired. Because no polar effect due to the transposon insertion is concerned in this case (Fig. 1A) and gene-specific allelic mutants exhibited consistent phenotypes, disruption of this gene is responsible for the altered pathogenesis. RSc1956 shared sequence homology with Escherichia coli murI, a gene encoding glutamate racemase. In bacteria, glutamate racemase catalyzes the conversion of L-glutamate to D-glutamate, an essential step in the synthesis of cell wall components and, thus, essential for the viability of bacteria (Doublet et al. 1993; Kada et al. 2004; Kimura et al. 2004; Liu et al. 1998). This is in disagreement with our current data, in which disruption of RSc1956 was not lethal on $R$. solanacearum. Blast search for murI homologues in GMI1000 genome revealed that RSc1956 is the only locus with significant sequence homology with murI, indicating that the inconsistency between our study and the $E$. coli study is probably not due to functional redundancy of homologous genes in the genome. Recent studies showed that, except for $E$. coli MurI proteins being present as monomers, MurI proteins form homo- or heterodimmers in gram-negative and -negative bacteria (Kim et al. 2007; Lundqvist et al. 2007; May et al. 2007). The crystal structural profiles of these enzymes further revealed two domains containing conserved amino acids involved in deprotonation of D- or Lglutamate, and distinct mechanisms of regulation for the family of these enzymes have also been reported (Lundqvist et al. 2007). In our mutant, Tn5 is inserted in the middle of RSc1956,

Table 4. In vitro growth and virulence groups of Ralstonia solanacearum mutants ${ }^{\mathrm{a}}$

\begin{tabular}{|c|c|c|c|c|}
\hline Transposon insertion site ${ }^{b}$ & TTC & TTC-SDS & M9/MS & Colony fluidity ${ }^{\mathrm{c}}$ \\
\hline Wild-type (nil) & $\ldots$ & $\ldots$ & $\ldots$ & + \\
\hline \multicolumn{5}{|l|}{ Mutants identified on tomato } \\
\hline $\operatorname{RSc} 2735(p h c B)$ & $=$ & $=$ & $=$ & - \\
\hline $\mathrm{RSc} 2748(p h c A)$ & $=$ & $=$ & $=$ & _- \\
\hline RSp0852 (hrpG) & $=$ & $=$ & $=$ & + \\
\hline $\mathrm{RSc} 2827$ (pilD) & $=$ & $\downarrow$ & $=$ & + \\
\hline RSc3111 ( $g s p L)$ & $=$ & $=$ & $=$ & + \\
\hline RSc3114 (gspD) & $=$ & $=$ & $=$ & + \\
\hline RSp1007 & $=$ & $=$ & $=$ & - \\
\hline RSc0571 ( pgk) & $\downarrow$ & $=$ & $x^{c}$ & + \\
\hline RSc1591 (hpaI1) & $=$ & $=$ & $=$ & + \\
\hline RSp1010 & $=$ & $=$ & $=$ & - \\
\hline $\operatorname{RSc} 3115(g s p E)$ & $=$ & $=$ & $=$ & + \\
\hline \multicolumn{5}{|c|}{ Mutants identified on Arabidopsis } \\
\hline $\mathrm{RSc} 0903(\operatorname{ser} C)$ & $=$ & $=$ & $x$ & + \\
\hline $\mathrm{RSc} 1981(\operatorname{trp} A)$ & $\downarrow \downarrow$ & $\downarrow$ & $x$ & + \\
\hline $\mathrm{RSc} 0454$ & $=$ & $=$ & $x$ & + \\
\hline RSc0411 & $\downarrow$ & $\downarrow \downarrow$ & $\downarrow$ & + \\
\hline $\mathrm{RSc} 0353($ gpmA) & $\downarrow \downarrow$ & $=$ & $x$ & + \\
\hline RSc1956 (murI) & $=$ & $=$ & $=$ & + \\
\hline $\mathrm{RSc} 0565(r f a F)$ & $=$ & $\downarrow$ & $=$ & + \\
\hline $\mathrm{RSc} 1326$ & $=$ & $=$ & $x$ & + \\
\hline $\mathrm{RSc} 2464(\operatorname{clp} A)$ & $\downarrow$ & $\downarrow$ & $\downarrow$ & + \\
\hline $\mathrm{RSc0734}$ (tolA) & $=$ & $\downarrow$ & $=$ & + \\
\hline $\mathrm{RSc} 0736$ (pal) & $=$ & $\downarrow$ & $=$ & + \\
\hline $\mathrm{RSc} 0732($ tolQ $)$ & $=$ & $\downarrow$ & $=$ & + \\
\hline $\mathrm{RSc} 2684$ (proC) & $\downarrow$ & $=$ & $x$ & + \\
\hline RSc1206 & $=$ & $x$ & $=$ & + \\
\hline $\operatorname{RSc} 0500(r u v B)$ & $=$ & $\downarrow$ & $=$ & + \\
\hline
\end{tabular}

${ }^{\text {a }}$ Bacterial growth at an estimated concentration of $10^{5}, 10^{4}, 10^{3}$, and $10^{2} \mathrm{CFU} / \mathrm{ml}$ was tested by spotting $10 \mu \mathrm{l}$ each on the indicated medium plates; TTC $=$ 2,3,5-triphenyl tetrazolium chloride medium, SDS = sodium dodecyl sulfate, M9 = minimal medium, and MS = Murashige and Skoog medium. Wild-type strains grew well on all media at all test concentrations. Growth of the mutants was evaluated relative to that of the wild-type strain: $=$ indicates not significantly different, $\downarrow$ indicates 10 -fold reduction, $\downarrow \downarrow$ indicates $\geq 10^{2}$-fold reduction, and $\times$ indicates no growth at all test concentrations.

${ }^{\mathrm{b}}$ Mutants with transposon insertion in the same locus exhibited consistent phenotypes on media. Data of a representative mutant strain is shown here.

${ }^{\mathrm{c}}$ Symbols: $+=$ similar fluidity with the wild-type strain and $-=$ no apparent exopolysaccharide (EPS) production.

Table 5. Reactions of Ralstonia solanacearum mutants in Pss 190 and Pss4 background when inoculated on 3-week-old tomato and 4-week-old Arabidopsis ${ }^{\mathrm{a}}$

\begin{tabular}{|c|c|c|c|c|c|c|c|c|c|c|c|c|}
\hline \multirow[b]{3}{*}{ Transposon $^{\mathbf{b}}$} & \multicolumn{6}{|c|}{ Tomato } & \multicolumn{6}{|c|}{ Arabidopsis } \\
\hline & \multicolumn{3}{|c|}{ In Pss190 background } & \multicolumn{3}{|c|}{ In Pss4 background } & \multicolumn{3}{|c|}{ In Pss190 background } & \multicolumn{3}{|c|}{ In Pss4 background } \\
\hline & Score & $\mathbf{B}(+/ \mathbf{T})$ & $\mathbf{M}(+/ \mathbf{T})$ & Score & $\mathbf{B}(+/ \mathbf{T})$ & $\mathbf{M}(+/ \mathbf{T})$ & Score & $\mathrm{C}(+/ \mathbf{T})$ & Mf $(+/ T)$ & Score & $\mathbf{C}(+/ \mathbf{T})$ & Mf $(+/ T)$ \\
\hline Wild-type (nil) & 5 & - & - & 5 & - & - & 3.8 & - & - & 3.4 & - & - \\
\hline RSc1956 (murI) & 0.4 & $5 / 11$ & $1 / 11$ & 0 & $5 / 12$ & $1 / 12$ & 0.4 & $6 / 7$ & $0 / 7$ & 0.4 & $13 / 13$ & $4 / 13$ \\
\hline $\mathrm{RSc} 0565(r f a F)$ & 1.3 & $0 / 8$ & $0 / 8$ & 0 & $0 / 12$ & $0 / 12$ & 0.3 & $1 / 8$ & $1 / 8$ & 0.3 & $1 / 13$ & $0 / 13$ \\
\hline RSc0734 (tolA) & 4.9 & - & - & 3.4 & - & - & 0.3 & $7 / 8$ & $3 / 8$ & 0.6 & $13 / 14$ & $7 / 14$ \\
\hline RSc0736 (pal) & 4.5 & - & - & 4.6 & - & - & 1.2 & $3 / 3$ & $1 / 3$ & 1.2 & $6 / 6$ & $4 / 6$ \\
\hline RSc0732 (tolQ) & 4.6 & - & - & 4.3 & - & - & 0.6 & $6 / 6$ & $2 / 6$ & 1.2 & $4 / 4$ & $2 / 2$ \\
\hline RSc1206 & 4.8 & - & - & 4.6 & - & - & 1.9 & $1 / 1$ & $0 / 1$ & 1.0 & $7 / 7$ & $7 / 7$ \\
\hline
\end{tabular}

${ }^{\text {a }}$ Score $=$ mean severity score based on symptom observed and the presence of $R$. solanacearum analyzed in different plant tissues 21 days postinoculation Presence of R. solanacearum on stem base (B) or midstem (M) of tomato, or collar (C) or midpoint (5 cm above stem) of flower stalk (Mf) of Arabidopsis presented as number of positive isolation $(+)$ versus number of total samples $(\mathrm{T}) ;-$ indicates that plants of the resistant reaction were not assayed.

${ }^{\mathrm{b}}$ Transposon insertion site. 
which could result in production of truncated proteins or partial inactivation of the putative RSc1956 gene product. This may potentially lead to disturbance in effective protein oligomerization or incomplete loss of the enzyme function and, thus, account for the inconsistency between our results and the previous report on E. coli. Moreover, previous studies have reported a requirement of proper intracellular glutamate metabolism for chemotaxis in Rhodobacter sphaeroides (Jacobs et al. 1995) and an important role of conserved glutamate residues in electrostatic interactions at the rotor-stator interface which controls flagellar speed of Sinorhizobium meliloti (Attmannspacher et al. 2005). It is currently not known whether the glutamate metabolism in $R$. solanacearum murI mutant is disturbed and how this can possibly affect movement of this mutant in the xylem of host plants. Further study of this gene will provide better insights into function of this protein.

\section{Differential requirement of virulence genes suggests adaptation of $R$. solanacearum in different host environments.}

In this study, a group of Ralstonia solanacearum mutants displaying differential pathogenesis on the two test plants was identified. These mutants mostly displayed normal growth on minimal media (except for the mutant disrupted in $\operatorname{clp} A$ or
proC), exhibited null or decreased pathogenicity on Arabidopsis plants, but retained virulence on tomato plants. Characterization of allelic mutants in strain Pss 190 or Pss4 background provided further support for the idea that the altered pathogenicity was due to the identified transposon insertions (Table 5; discussed below). Loci disrupted in these mutants included genes involved in protein degradation $(\operatorname{clp} A)$, components of transporter proteins (tolA and tolQ), and lipoprotein production ( $\mathrm{pal}$ and RSc1206).

The identified loci or their associated genes of this group of mutants have been demonstrated or implicated in bacterial stress response or pathogenesis. For example, protein degradation mediated by Clp protein plays a role in bacterial stress response and pathogenesis (Capestany et al. 2008; Jenal and Hengge-Aronis 2003). In this study, independent insertional mutants of $\operatorname{clp} A$ exhibiting consistent phenotypes were isolated and no polar effect was concerned (Fig. 1B), suggesting that disruption of $\mathrm{ClpA}$ function is responsible for the altered pathogenesis. Moreover, in addition to conferring tolerance to chemical stresses, the Tol-Pal transport systems have been demonstrated to be involved in pathogenesis of bacteria pathogenic to animals or plants (Dubuisson et al. 2005; Fortney et al. 2000; Heilpern and Waldor 2000; Hellman et al. 2002). In current study, independent allelic Pss190 and Pss4 mutants in

Table 6. Colonization of selected Ralstonia solanacearum Pss190 mutants in 3-week-old tomato and 4-week-old Arabidopsis ${ }^{\mathrm{a}}$

\begin{tabular}{|c|c|c|c|c|c|c|c|c|c|c|}
\hline \multirow[b]{3}{*}{ Transposon insertion site } & \multicolumn{5}{|c|}{ Tomato } & \multicolumn{5}{|c|}{ Arabidopsis } \\
\hline & \multirow[b]{2}{*}{$\mathbf{B}+/ \mathbf{T}^{\mathbf{b}}$} & \multicolumn{2}{|c|}{ B } & \multicolumn{2}{|c|}{$\mathbf{M}$} & \multirow[b]{2}{*}{$\mathbf{C}+/ \mathbf{T}^{\mathrm{b}}$} & \multicolumn{2}{|c|}{$\mathbf{C}$} & \multicolumn{2}{|c|}{ Mf } \\
\hline & & Mean & $P$ value & Mean & $P$ value & & Mean & $P$ value & Mean & $P$ value \\
\hline Wild-type (nil) & $18 / 18$ & 9.1 & & 9.3 & & $30 / 30$ & 9.9 & & 9.7 & \\
\hline $\mathrm{RSc} 0734$ (tolA) & $11 / 18$ & 9.7 & 0.0673 & 8.8 & 0.6216 & $24 / 24$ & 9.0 & 0.0002 & 2.6 & $<0.0001$ \\
\hline RSc0736 (pal-1) & $16 / 18$ & 8.9 & 0.6210 & 8.7 & 0.4748 & $30 / 30$ & 9.4 & 0.0004 & 5.5 & $<0.0001$ \\
\hline RSc0736 (pal-2) & $16 / 18$ & 9.0 & 0.8673 & 8.2 & 0.2955 & $30 / 30$ & 9.4 & 0.0038 & 6.7 & $<0.0001$ \\
\hline $\mathrm{RSc} 0732$ (tolQ) & $15 / 18$ & 9.0 & 0.7718 & 8.0 & 0.2236 & $30 / 30$ & 9.0 & $<0.0001$ & 2.5 & $<0.0001$ \\
\hline RSc1206 & $18 / 18$ & 9.3 & 0.6101 & 9.4 & 0.7985 & $30 / 30$ & 9.7 & 0.1405 & 7.9 & 0.0055 \\
\hline
\end{tabular}

${ }^{a}$ Plants were incubated at $26^{\circ} \mathrm{C}$ in growth chambers postinoculation. Means of bacterial population (CFU/gram plant tissue) in different plant tissues: stem base (B) or midstem (M) of tomato, or collar (C) or midpoint (5 cm above stem) of flower stalk (Mf) of Arabidopsis. P values for test of significance between wild type and each mutant are given based on Student $t$ test.

${ }^{\mathrm{b}}$ Number of plants with positive detection of the pathogen in stem base (B+) of tomato 7 days postinoculation (DPI) and in collar of Arabidopsis 21 DPI $(\mathrm{C}+)$ versus number of total samples $(\mathrm{T})$.

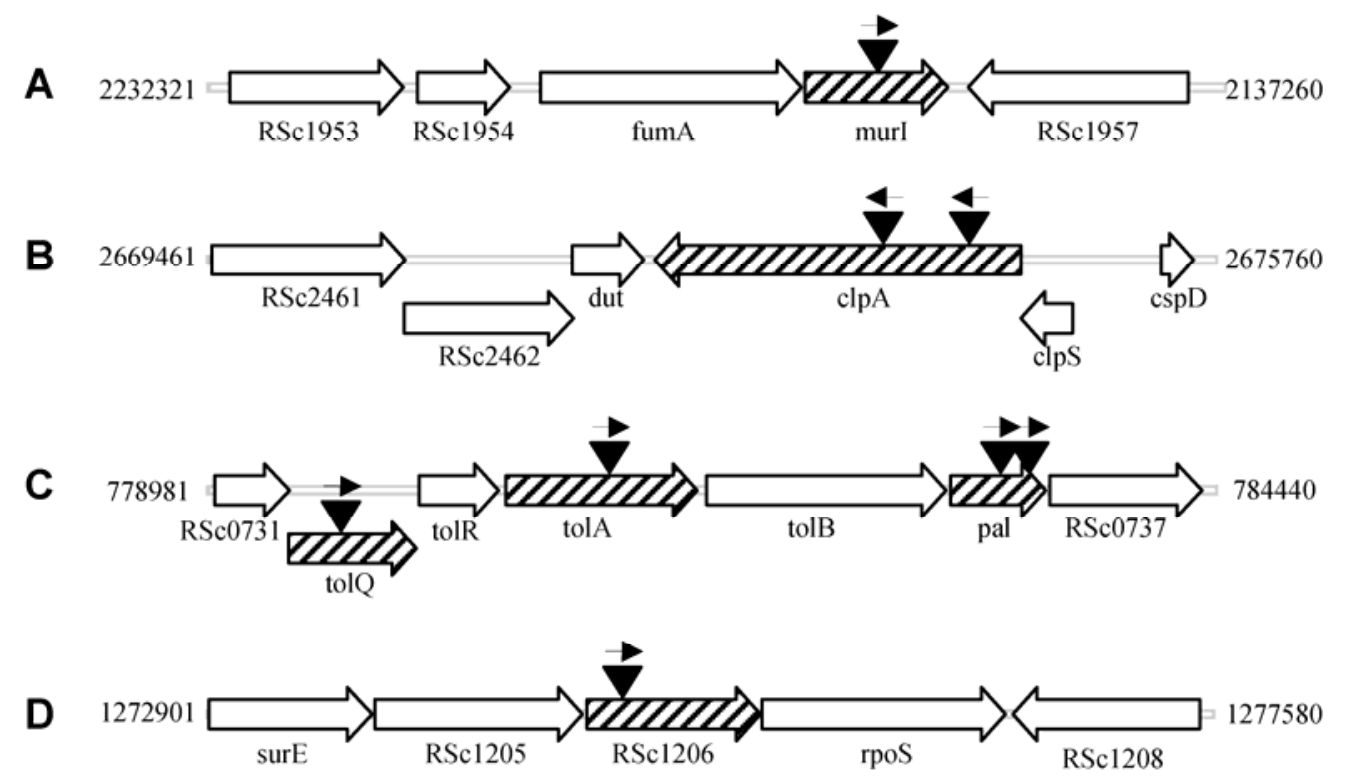

Fig. 1. Genomic locations and orientations of transposon in selected mutants of Ralstonia solanacearum. Numbers to the left and right are genome sequence coordinates in base pairs. Gene numbers or products are shown below disrupted and selected flanking genes. Genes inserted by transposon are represented by hatched block arrows. Transposon insertions are shown as inverted triangles, and the orientation of the $n p t I I$ promoter in each insertion is indicated by an arrow above the triangle. 
the tol-pal cluster exhibited consistent altered phenotypes. Although it is not known whether polar effect occurred on the gene downstream of pal due to transposon insertion (Fig. 1C), our results, along with the observations of the previous reports describing involvement of the tol-pal cluster in bacterial pathogenesis, strongly supports a role for the $R$. solanacearum tolpal cluster in pathogenesis. Furthermore, the lipoprotein NLPD, encoded by the homologue $n l p D$ of RSc1206, has been indicated for its role in bacterial stationary survival (Streit et al. 2000). RpoS, a sigma factor encoded by the last gene (RSc1207), located in the putative RSc1206-associated operon, is an essential regulator for bacterial survival under various stresses (Rychlik and Barrow 2005; Saint-Ruf and Matic 2006; White-Ziegler et al. 2008) as well as for pathogenesis (Nielsen et al. 2006). Although a polar effect on $\operatorname{rpoS}$ function due to transposon insertion may also contribute to the altered phenotypes (Fig. 1D), the increased sensitivity of allelic mutants in different $R$. solanacearum strains to SDS is consistent with the phenotype associated with disruption of cell integrity. This supports involvement of the putative RSc1206-encoded lipoprotein in the altered phenotypes.

This group of mutants largely exhibited slightly lower multiplication in minimal medium. They mostly conferred normal colonization in Arabidopsis stem base but were impaired in systemic upward movement into flower stalk (Tables 3 and 5). Consistent with these results and the roles of these genes in stress response, spatial quantitative assessments of bacterial colonization in plants showed that the mutants colonized similarly to the wild-type strain in tomato plants but displayed slightly reduced colonization in the Arabidopsis stem base and were considerably impaired in further colonization in the Arabidopsis flower stalk (Table 6). These results indicate that these mutants are incapable of colonizing in the stressful environment in Arabidopsis as they colonize in tomato, thus leading to differential pathogenesis. The defective growth of the mutants in the presence of SDS (Table 4) also echoes reduced stress tolerance. Together, the well-established roles of the identified genes in bacterial stress response and our data suggest that $R$. solanacearum is equipped to adapt to different environments in various host plants. Future studies of the presence and differential expression of these stress-related genes in different hosts would provide a better understanding of the pathogen's adaptability mechanisms.

\section{Effectiveness and coverage of mutant screenings.}

In our mutant screenings, as expected, the tomato screening system using stem puncture inoculation allowed identification of known pathogenicity genes ( $p h c A, p h c B, h r p G$, pilD, gspL, $g s p D$, and $g s p E$ ) (Genin and Boucher 2004; Liu et al. 2001, 2005; Schell 2000). Similarly, the Arabidopsis seedling assay identified $r f a F$, an essential gene for $R$. solanacearum pathogenesis (Titarenko et al. 1997). Successful isolation of these mutants confirmed the effectiveness of our screenings. Furthermore, our screenings led to the identification of new pathogenesis-related factors (discussed below). Nevertheless, despite identifying a group of known and new pathogenicity genes, none of the type III effectors was identified in this study using the described screening methods. This agrees with the view that individual mutations in such genes do not have a dramatic effect on bacterial virulence (Cunnac et al. 2004).

Although multiple independent mutants disrupted in the same genes were isolated in our screenings, the current size of the mutant pools screened in this study (approximately 3,000 mutants) was not sufficient to saturate the $R$. solanacearum genome with transposition events. Furthermore, to our surprise, all of the loci identified on Arabidopsis and most of the loci identified on tomato were mapped on the chromosome using the GMI1000 genome organization as a reference. Thus, additional pathogenesis-defective mutants will be identified by further increasing the mutant bank size. Moreover, other screening approaches may complement transposon mutagenesis. For example, Brown and Allen (2004) have used IVET to screen for $R$. solanacearum genes expressed during bacterial growth on tomato plants, aiming to identify possible pathogenicity genes. Interestingly, loci related to the genes identified in our study were not identified by IVET, except for those containing RSc2827 (pilD) and RSc1207 (rpoS), suggesting complementarities of these experimental approaches.

\section{MATERIALS AND METHODS}

\section{Bacterial strains and culture conditions.}

Media used for this study included TTC medium (Denny and Hayward 2001), modified SM1 medium (TTC medium supplemented with $0.01 \%$ polymyxin B sulfate, $0.002 \%$ tyrothricin, $0.005 \%$ chloramphenicol, $0.005 \%$ cycloheximide, and $0.005 \%$ crystal violet) (Tsai et al. 1985), TTC-SDS medium (TTC medium supplemented with $0.01 \%$ SDS), 523 medium $(0.03 \%$ magnesium sulfate heptahydrate, $0.2 \%$ potassium phosphate, $0.4 \%$ yeast extract, $0.8 \%$ casein hydrolysate, $1 \%$ sucrose, and $1.5 \%$ Bacto agar), and M9 medium (Sambrook et al. 1989).

For analysis of in vitro growth of $R$. solanacearum in various media, the bacterial stocks were streaked out from $-80^{\circ} \mathrm{C}$ onto the TTC plate containing kanamycin $(100 \mu \mathrm{g} / \mathrm{ml})$, incubated at $28^{\circ} \mathrm{C}$ for 2 days and single colonies were transferred and grown in 523 medium broth at $28^{\circ} \mathrm{C}$ for 2 days. The bacterial suspensions were then diluted with sterile distilled water to give an optical density of 0.3 at $600 \mathrm{~nm}$ (approximately $10^{8}$ $\mathrm{CFU} / \mathrm{ml}$ ) followed by 10 -fold serial dilutions up to $10^{5}$. Each diluted bacterial sample $(10 \mu \mathrm{l})$ was spotted onto the indicated medium plates. Bacterial growth on each medium was recorded 2 or 3 days after incubation at $28^{\circ} \mathrm{C}$ based on whether colonies showed at different dilutions. Colony fluidity of mutants was evaluated and compared with the wild-type strain as well, based on the morphology of colonies that grew on TTC plate containing kanamycin. In addition, growth of selected mutant strains was monitored in liquid minimal medium (M9) by measuring changes in optical density over time.

The wild-type strains used in this study included Pss190 (phylotype I, biovar 4) and Pss4 (phylotype I, biovar 3) that were isolated from tomato in Taiwan. An $R$. solanacearum mutant library was generated in the background of Pss190 using the EZ-Tn5 <KAN-2> kit (Epicentre, Madison, WI, U.S.A.) following the manufacturer's instructions. Aliquots of the electroporated cells were plated onto TTC medium plates containing kanamycin $(100 \mu \mathrm{g} / \mathrm{ml})$. Following 2 days of incubation at $28^{\circ} \mathrm{C}$, all colonies were picked, cultured in 523 medium for 2 days, and stored in $30 \%$ glycerol at $-80^{\circ} \mathrm{C}$.

Allelic mutants in the background of Pss4 were generated following a method described by Boucher and associates (1985) with modifications. Briefly, $R$. solanacearum cells were grown for 36 to $48 \mathrm{~h}$ at $28^{\circ} \mathrm{C}$ in one-quarter-strength M63 medium (Sambrook et al. 1989) supplemented with $0.2 \%$ glucose and $0.4 \%$ glycerol. The cell suspension $(40 \mu \mathrm{l})$ was mixed with $20 \mu \mathrm{l}(10 \mathrm{ng})$ of donor genomic DNA of Tn5 insertional mutants (resistant to kanamycin at $100 \mu \mathrm{g} / \mathrm{ml}$ ), followed by an incubation for $48 \mathrm{~h}$ at $28^{\circ} \mathrm{C}$ on CPG agar medium (Denny and Hayward 2001). The agar containing the bacteria was sliced out and the cells were suspended in $1 \mathrm{ml}$ of sterile $\mathrm{H}_{2} \mathrm{O}$ by vortexing. The supernatant was then transferred into a new microcentrifuge tube and the bacterial cells were harvested by brief centrifugation. The collected cells were resuspended in $100 \mu \mathrm{l}$ of sterile $\mathrm{H}_{2} \mathrm{O}$ and plated on TTC agar plate containing kana- 
mycin. Candidate colonies appeared after incubation for 48 to $72 \mathrm{~h}$ at $28^{\circ} \mathrm{C}$ and were further validated by checking the presence of Tn5 in the test genes using regular polymerase chain reaction using a gene-specific primer and a primer design based on the kanamycin resistance gene.

\section{Mutant screening and pathogenesis assays on tomato plants.}

Tomato (Solanum lycopersicum) L390, a cultivar susceptible to $R$. solanacearum, was used for mutant screening and pathogenesis assays. Seedlings, 3 weeks of age from the time seed were planted in potting mixture, were inoculated with either of the two methods. For the stem puncture method, bacterial mass of a 24-h culture on TTC agar medium containing kanamycin was touched with a sharp toothpick and then introduced directly into the axil of the second fully expended leaf. For each mutant strain, three plants were inoculated in each replication and the experiment was replicated three times, giving a total of nine test plants. The other inoculation method involved soil drench without root severing, as described by Jaunet and Wang (1999). The concentration of bacterial inoculum was $10^{8}$ $\mathrm{CFU} / \mathrm{ml}$. For each mutant strain, 6 plants were inoculated in each replication and the experiment was repeated twice over time, giving a total of 12 test plants. Inoculated plants were kept in a greenhouse with natural light at a mean temperature of $28^{\circ} \mathrm{C}$. In some comparative experiments, reactions of tomato plants inoculated with the soil drench method without root severing and incubated at $28^{\circ} \mathrm{C}$ were compared with root severing and incubation at $25^{\circ} \mathrm{C}$. Such experiments were carried out in both growth chambers and greenhouses with continuous temperature control and monitoring. Tomato roots were severed with a knife cutting into soil 1 to $2 \mathrm{~cm}$ away from the stem base at one side of the plant. The root-severed plants were promptly drenched with bacterial inoculum. Disease severity rating progress was conducted once a week for 3 weeks with a scoring system ranging from 0 to 5 , where $0=$ no symptoms, $1=$ one leaf partially wilted, $2=$ two to three leaves wilted, $3=$ all except the top two or three leaves wilted, $4=$ all leaves wilted, and $5=$ plant dead. Under these defined conditions, the wild-type strain Pss 190 caused complete wilting on tomato plants within 7 and 4 DPI when soil drench and stem puncture inoculation methods, respectively, were used. At the end of the observation period, symptomless plants of the mutant showing resistance reaction (mean score lower than 3.0) were selected for colonization test by a tissue printing method. The stem of each sampled plant was harvested by removing all leaves and roots, surface sterilized with $70 \%$ alcohol, and air dried. Cuts were made on each plant at the stem base and at midstem with sterile blades, respectively. Each of the cut surfaces was pressed tightly on SM1 (containing kanamycin) agar plate surfaces for $5 \mathrm{~s}$ per print; four prints per cut surface were made sequentially and the agar plates were incubated at $28^{\circ} \mathrm{C}$ for 3 days. If the bacterium appeared on any of the four prints of each sample, it was recorded as positive. If the bacterium was absent on all of the prints, it was recorded as negative.

When the in planta population of mutants in tomato plants was assessed, plants were incubated at $26^{\circ} \mathrm{C}$ postinoculation in growth chambers. Tissue segments (approximately $1 \mathrm{~cm}$ in length) were removed from the midstem and stem base of each plant, and weighted and crushed in $1 \mathrm{ml}$ of sterilized water. Tissue extract $(100 \mu \mathrm{l})$ was subjected to 10 -fold serial dilutions. Diluted wild-type and mutant bacterial samples $(10 \mu \mathrm{l}$ each) were spotted onto SM1 and TTC-kanamycin agar medium, respectively. The mutants were spotted on TTC-kanamycin medium rather than SM1 because some mutants displayed reduced growth in SM1 medium. The number of bacte- rial colonies was recorded 2 days after incubation at $28^{\circ} \mathrm{C}$. Pairwise mean comparisons of the in planta bacterial population at the stem base and midstem were made between each mutant and the wild type with the Student $t$ test method.

\section{Mutant screening and pathogenesis assays on Arabidopsis.}

For mutant screening carried out on Arabidopsis, seed of ecotype Col0 were surface sterilized with $70 \%$ ethanol for 1 min, treated with $10 \%$ sodium hypochlorite for $20 \mathrm{~min}$, washed five times with sterile water, then stored at $4^{\circ} \mathrm{C}$ for vernalization. Before sowing the seed on the MS medium (Gibco, Bethesda, MD, U.S.A.) supplemented with $1 \%$ sucrose ( $\mathrm{pH}$ 5.7 ) and $0.4 \%$ phytagel, $5 \mathrm{ml}$ of bacterial suspension of the tested strain with an optical density of 0.4 at $600 \mathrm{~nm}$ was poured onto each plate, left for $5 \mathrm{~min}$, and then poured off the plate. The vernalized seed were then spread uniformly on the plates and incubated under a $16-\mathrm{h}$ photoperiod at $28^{\circ} \mathrm{C}$. Survival rate of seedlings was monitored every week over 2 weeks to select mutants defective in pathogenesis. Under this experimental condition, the wild-type strain Pss 190 was able to kill $100 \%$ of the young seedlings within 2 weeks, whereas germinating seed inoculated with sterile water grew normally. The bacteria did not multiply visibly on MS medium until the death of Arabidopsis seedlings. This was followed by the rapid appearance of significant bacterial multiplication surrounding the dead tissues.

For pathogenesis assays of most $R$. solanacearum mutants carried out on older Arabidopsis plants, 4-week-old plants grown in potting mixture were removed from plug trays (1.5 $\mathrm{cm}$ in diameter). Half of the roots of each plant were trimmed off horizontally. The trimmed plants were transplanted into 2in. pots containing peat moss (Tref Ego Substratum B.V., Moerdijk, The Netherlands). Right after transplanting, $20 \mathrm{ml}$ of bacterial suspension $\left(10^{8} \mathrm{CFU} / \mathrm{ml}\right)$ was drenched around the stem base. The inoculated plants were grown in a growth chamber at $25^{\circ} \mathrm{C}$ under a 16 -h photoperiod. Symptom development was recorded every 3 days with a scoring system ranging from 0 to 4 , where $0=$ no symptoms, $1=$ one to two cauline leaves wilted, $2=$ one-third of cauline leaves wilted, $3=$ twothirds of cauline leaves wilted, and $4=$ all cauline leaves wilted. At the end of the observation period, symptomless plants of the mutants showing a resistance reaction (mean score lower than 2.4) were harvested for a colonization test. All leaves were removed; the three longest flower stalks were kept and the others discarded. The entire plant was then surface sterilized by thorough spray with $70 \%$ alcohol. For each test plant, tissue segments (approximately $0.5 \mathrm{~cm}$ in length) were cut from the stem base (between root and cauline leaves) and from three flower stalks at the position $5 \mathrm{~cm}$ above stem. The tissue segments were placed on SM1 agar medium containing kanamycin and incubated at $30^{\circ} \mathrm{C}$ for 3 days. The number of stem bases or flower stalks showing the presence of the bacterium was recorded. For each mutant strain, 3 plants were inoculated in each experiment and the experiment was repeated four times, giving a total of 12 test plants.

When the in planta population of mutants in Arabidopsis plants was assessed, plants were incubated at $26^{\circ} \mathrm{C}$ postinoculation in growth chambers. For each test plant, tissue segments were cut from the stem base and three flower stalks (approximately $1 \mathrm{~cm}$ in length). The tissue segments were weighted and crushed in $200 \mu \mathrm{l}$ of sterilized water. Tissue extract $(20 \mu \mathrm{l})$ was subjected to 10 -fold serial dilutions. Diluted wild-type and mutant bacterial samples $(10 \mu \mathrm{l}$ each) were spotted onto SM1 and TTC-kanamycin agar medium, respectively, and the number of bacterial colonies was recorded 2 days after incubation at $28^{\circ} \mathrm{C}$. Statistic analysis was conducted with a Student's $t$ test as described above. 
Determination of the disrupted loci.

Bacterial genomic DNA was isolated using a MasterPure DNA Purification kit (Epicentre) and subjected to direct sequencing using Tn5-specific primers following the protocols described previously (Epicentre) (Hoffman and Jendrisak 1999). The sequences of the primers used for the sequencing were 5'-ACCTACAACAAAGCTCTCATCAACC-3' or 5'GCAATGTAACATCAGAGATTTTGAG-3'. To determine the identity of the disrupted loci, the identified flanking sequences were then compared with the GenBank databases using BLASTN. The genes and loci were designated based on the GMI1000 genome.

\section{ACKNOWLEDGMENTS}

We thank C. Boucher for providing access to the genome sequence database and genomic DNA of $R$. solanacearum strains Molk2 and IPO1609, and for his careful review of this manuscript. This work was supported by grants (92-2313-B-001-015 and 94-2313-B-002-119) from the National Science Council of Taiwan, Republic of China, to C.-P. Cheng. This work has been carried out in compliance with local regulations on genetic recombination experimentation.

\section{LITERATURE CITED}

Attmannspacher, U., Scharf, B., and Schmitt, R. 2005. Control of speed modulation (chemokinesis) in the unidirectional rotary motor of $\mathrm{Si}$ norhizobium meliloti. Mol. Microbiol. 56:708-718.

Boucher, C. A., Barberis, P. A., Trigalet, A. P., and Demery, D. A. 1985. Transposon mutagenesis of Pseudomonas solanacearum: Isolation of Tn5-induced avirulent mutants. J. Gen. Microbiol. 131:2449-2457.

Brown, D. G., and Allen, C. 2004. Ralstonia solanacearum genes induced during growth in tomato: An inside view of bacterial wilt. Mol. Microbiol. 53:1641-1660.

Capestany, C. A., Tribble, G. D., Maeda, K., Demuth, D. R., and Lamont, R. J. 2008. Role of the Clp system in stress tolerance, biofilm formation, and intracellular invasion in Porphyromonas gingivalis. J. Bacteriol. 190:1436-1446.

Cunnac, S., Occhialini, A., Barberis, P., Boucher, C., and Genin, S. 2004. Inventory and functional analysis of the large Hrp regulon in Ralstonia solanacearum: Identification of novel effector proteins translocated to plant host cells through the type III secretion system. Mol. Microbiol. 53:115-128

Denny, T. P. 2006. Plant pathogenic Ralstonia species. Pages 573-644 in: Plant-Associated Bacteria. S. S. Gnanamanickam, ed. Springer Publishing, Dordrecht, The Netherlands.

Denny, T. P., and Baek, S. R. 1991. Genetic evidence that extracellular polysaccharide is a virulence factor of Pseudomonas solanacearum. Mol. Plant-Microbe Interact. 4:198-206.

Denny, T. P., and Hayward, A. C. 2001. Ralstonia solanacearum, Pages 151-173 in: Laboratory Guide for Identification of Plant Pathogenic Bacteria, 3rd ed. N. W. Schaad, J. B. Jones, and W. Chun, eds. American Phytopathological Society Press, St. Paul, MN, U.S.A.

Deslandes, L., Peeters, N., Feng, D. X., Khounlotham, M., Boucher, C., Somssich, I., Genin, S., and Marco, Y. 2003. Physical interaction between RRS1-R, a protein conferring resistance to bacterial wilt, and PopP2, a type III effector targeted to the plant nucleus. Proc. Natl. Acad. Sci. U.S.A. 100:8024-8029.

Doublet, P., van Heijenoort, J., Bohin, J. P., and Mengin-Lecreulx, D. 1993. The murI gene of Escherichia coli is an essential gene that encodes a glutamate racemase activity. J. Bacteriol. 175:2970-2979.

Dubuisson, J. F., Vianney, A., Hugouvieux-Cotte-Pattat, N., and Lazzaroni, J. C. 2005. Tol-Pal proteins are critical cell envelope components of Erwinia chrysanthemi affecting cell morphology and virulence. Microbiology 151:3337-3347.

Fortney, K. R., Young, R. S., Bauer, M. E., Katz, B. P., Hood, A. F., Munson, R. S. Jr., and Spinola, S. M. 2000. Expression of peptidoglycan-associated lipoprotein is required for virulence in the human model of Haemophilus ducreyi infection. Infect. Immun. 68:6441-6448.

Gabriel, D. W., Allen, C., Schell, M., Denny, T. P., Greenberg, J. T., Duan, Y. P., Flores-Cruz, Z., Huang, Q., Clifford, J. M., Presting, G., Gonzalez, E. T., Reddy, J., Elphinstone, J., Swanson, J., Yao, J., Mulholland, V., Liu, L., Farmerie, W., Patnaikuni, M., Balogh, B., Norman, D., Alvarez, A., Castillo, J. A., Jones, J., Saddler, G., Walunas, T., Zhukov, A., and Mikhailova, N. 2006. Identification of open reading frames unique to a select agent: Ralstonia solanacearum race 3 biovar 2. Mol. Plant-
Microbe Interact. 19:69-79.

Genin, S., and Boucher, C. 2004. Lessons learned from the genome analysis of Ralstonia solanacearum. Annu. Rev. Phytopathol. 42:107-134.

Godiard, L., Sauviac, L., Torii, K. U., Grenon, O., Mangin, B., Grimsley, N. H., and Marco, Y. 2003. ERECTA, an LRR receptor-like kinase protein controlling development pleiotropically affects resistance to bacterial wilt. Plant J. 363:353-65.

González, E. T., Brown, D. G., Swanson, J. K., and Allen, C. 2007. Using the Ralstonia solanacearum Tat secretome to identify bacterial wilt virulence factors. Appl. Environ. Microbiol. 73:3779-3786.

Hayward, A. C. 1991. Biology and epidemiology of bacterial wilt caused by Pseudomonas solanacearum: Annu. Rev. Phytopathol. 29:65-87.

Heilpern, A. J., and Waldor, M. K. 2000. CTXphi infection of Vibrio cholerae requires the tolQRA gene products. J. Bacteriol. 182:1739-1747.

Hellman, J., Roberts, J. D., Jr., Tehan, M. M., Allaire, J. E., and Warren, H. S. 2002. Bacterial peptidoglycan-associated lipoprotein is released into the bloodstream in gram-negative sepsis and causes inflammation and death in mice. J. Biol. Chem. 277:14274-14280.

Hirsch, J., Deslandes, L., Feng, D. X., Balagué, C., and Marco, Y. 2002. Delayed symptom development in ein2-1, an Arabidopsis ethylene insensitive mutant, in response to bacterial wilt caused by Ralstonia solanacearum. Phytopathology 92:1142-1148.

Hoffman, L., and Jendrisak, J. 1999. Use of EZ::TN Transposomes for genetic analysis and direct sequencing of bacterial genomic DNA. Epicentre Forum 6:1-4.

Hsu, S. T., Hsu, S. T., Hong, W. F., Tzeng, K. C., and Chen, C. C. 1993. Bacterial wilt of perilla caused by Pseudomonas solanacearum and its transmission. Plant Dis. 77:674-677.

Huang, J., and Schell, M. 1995. Molecular characterization of the eps gene cluster of Pseudomonas solanacearum and its transcriptional regulation at a single promoter. Mol. Microbiol. 16:977-989.

Jacobs, M. H. J., van der Heide, T., Tolner, B., Driessen, A. J. M., and Konings, W. N. 1995. Expression of the gltP gene of Escherichia coil in a glutamate transport-deficient mutant of Rhodobacter sphaeroides restores chemotaxis to glutamate. Mol. Microbiol. 18:641-647.

Jaunet, T. X., and Wang, J. F. 1999. Variation in genotype and aggressiveness of Ralstonia solanacearum race 1 isolated from tomato in Taiwan. Phytopathology 89:320-327.

Jenal, U., and Hengge-Aronis, R. 2003. Regulation by proteolysis in bacterial cells. Curr. Opin. Microbiol. 6:163-172.

Kada, S., Nanamiya, H., Kawamura, F., and Horinouchi, S. 2004. Glr, a glutamate racemase, supplies D-glutamate to both peptidoglycan synthesis and poly-gamma-glutamate production in gamma-PGA-producing Bacillus subtilis. FEMS (Fed. Eur. Microbiol. Soc.) Microbiol. Lett. 236:13-20.

Kim, K. H., Bong, Y. J., Park, J. K., Shin, K. J., Hwang, K. Y., and Kim, E. E. 2007. Structural basis for glutamate racemase inhibition. J. Mol. Biol. 372:434-443.

Kimura, K., Tran, L. S., Uchida, I., and Itoh, Y. 2004. Characterization of Bacillus subtilis gamma-glutamyltransferase and its involvement in the degradation of capsule poly-gamma-glutamate. Microbiology 150:4115-4123.

Liu, H., Kang, Y., Genin, S., Schell, M. A., and Denny, T. P. 2001. Twitching motility of Ralstonia solanacearum requires a type IV pilus system. Microbiology 147:3215-3229.

Liu, H., Zhang, S., Schell, M. A., and Denny, T. P. 2005. Pyramiding unmarked deletions in Ralstonia solanacearum shows that secreted proteins in addition to plant cell-wall-degrading enzymes contribute to virulence. Mol. Plant-Microbe Interact. 18:1296-1305.

Liu, L., Yoshimura, T., Endo, K., Kishimoto, K., Fuchikami, Y., Manning, J. M., Esaki, N., and Soda, K. 1998. Compensation for D-glutamate auxotrophy of Escherichia coli WM335 by D-amino acid aminotransferase gene and regulation of murI expression. Biosci. Biotechnol. Biochem. 62:193-195.

Lundqvist, T., Fisher, S. L., Kern, G., Folmer, R. H., Xue, Y., Newton, D. T., Keating, T. A., Alm, R. A., and de Jonge, B. L. 2007. Exploitation of structural and regulatory diversity in glutamate racemases. Nature 447:817-822.

May, M., Mehboob, S., Mulhearn, D. C., Wang, Z., Yu, H., Thatcher, G. R., Santarsiero, B. D., Johnson, M. E., and Mesecar, A. D. 2007. Structural and functional analysis of two glutamate racemase isozymes from Bacillus anthracis and implications for inhibitor design. J. Mol. Biol. 371:1219-1237.

Mole, B. M., Baltrus, D. A., Dangl, J. L., and Grant, S. R. 2007. Global virulence regulation networks in phytopathogenic bacteria. Trends $\mathrm{Mi}$ crobiol. 15:363-371.

Nielsen, A. T., Dolganov, N. A., Otto, G., Miller, M. C., Wu, C. Y., and Schoolnik, G. K. 2006. RpoS Controls the Vibrio cholerae mucosal escape response. PLoS Pathog. 2:0933-0948.

Pan, C. M., Lin, Y. S., and Hsu, S. T. 1996. Bacterial wilt, a new disease of 
loofah caused by Pseudomonas solanacearum. Plant Pathol. Bull. 38:295-312.

Rychlik, I., and Barrow, P. A. 2005. Salmonella stress management and its relevance to behaviour during intestinal colonisation and infection. FEMS (Fed. Eur. Microbiol. Soc.) Microbiol. Rev. 29:1021-1040.

Saint-Ruf, C., and Matic, I. 2006. Environmental tuning of mutation rates. Environ. Microbiol. 8:193-199.

Salanoubat, M., Genin, S., Artiguenave, F., Gouzy, J., Mangenot, S., Arlat, M., Billault, A., Brottier, P., Camus, J. C., Cattolico, L., Chandler, M., Choisne, N., Claudel-Renard, C., Cunnac, S., Demange, N., Gaspin, C., Lavie, M., Moisan, A., Robert, C., Saurin, W., Schiex, T., Siguier, P., Thebault, P., Whalen, M., Wincker, P., Levy, M., Weissenbach, J., and Boucher, C. A. 2002. Genome sequence of the plant pathogen Ralstonia solanacearum. Nature 415:497-502.

Sambrook, J., Fritsch, E. F., and Maniatis, T. 1989. Molecular Cloning: A Laboratory Manual, Vol. 3, 2nd ed. Cold Spring Harbor Laboratory Press, Cold Spring Harbor, NY, U.S.A.

Schell, M. A. 2000. Control of virulence and pathogenicity genes of Ralstonia Solanacearum by an elaborate sensory network. Annu. Rev. Phytopathol. 38:263-292.

Streit, W. R., Hofmann, K., and Liebl, W. 2000. Molecular characterization of the Sinorhizobium meliloti nlpD gene. Arch. Microbiol. 174:292-295.

Su, C. C., and Leu, L. S. 1995. Bacterial wilt of anthurium caused by Pseudomonas solanacearum. Plant Pathol. Bull. 4:34-38.
Titarenko, E., Lopez-Solanilla, E., Garcia-Olmedo, F., and RodriguezPalenzuela, P. 1997. Mutants of Ralstonia (Pseudomonas) solanacearum sensitive to antimicrobial peptides are altered in their lipopolysaccharide structure and are avirulent in tobacco. J. Bacteriol. 179:66996704.

Tsai, J. W., Hsu, S. T., and Chen, L. C. 1985. Bacteriocin-producing strains of Pseudomonas solanacearum and their effect on development of bacterial wilt of tomato. Plant Prot. Bull. 27:267-278.

Wang, J. F., Hanson, P. M., and Barnes, J. A. 1998. Worldwide evaluation of an international set of resistance sources to bacterial wilt in tomato. Pages 269-275 in: Bacterial Wilt Disease: Molecular and Ecological Aspects. P. Prior, C. Allen, and J. Elphinstone, eds. Springer-Verlog, Berlin.

White-Ziegler, C. A., Um, S., Pérez, N. M., Berns, A. L., Malhowski, A. J., and Young, S. 2008. Low temperature $\left(23^{\circ} \mathrm{C}\right)$ increases expression of biofilm-, cold-shock- and RpoS-dependent genes in Escherichia coli K-12. Microbiology 154:148-166.

\section{AUTHOR-RECOMMENDED INTERNET RESOURCES}

Genopole's Ralstonia solanacearum website: bioinfo.genopole-toulouse.prd.fr/annotation/iANT/bacteria/ralsto National Center for Biotechnology Information website: www.ncbi.nlm.nih.gov 